\title{
Treatment of Tannery Effluent by Locally Available Commercial Grade Lime
}

\author{
M. A. Sabur*, M. M. Rahman, and S. Safiullah \\ Department of Chemistry, Jahangirnagar University, Bangladesh
}

Received 11 August 2012, accepted in final revised form 23 December 2012

\begin{abstract}
The treatment of tannery effluent was carried out based on the locally available commercial grade lime. Collected tannery effluent was acidic ( $\mathrm{pH} 3.94)$ in nature with total chromium content, chemical oxygen demand (COD), total suspended solids (TSS), total dissolved solids (TDS) and the conductivity at $30^{\circ} \mathrm{C}$ were $987 \mathrm{mg} / \mathrm{L}, 3175.32 \mathrm{mg} \mathrm{O} / \mathrm{L}, 22915 \mathrm{mg} / \mathrm{L}$, $13360 \mathrm{mg} / \mathrm{L}$ and $60.7 \mathrm{mS} / \mathrm{cm}$, respectively. The effluent was treated by chemical precipitation method and the dependency on $\mathrm{pH}$ in the treatment was investigated by altering the $\mathrm{pH}$ from 6.0 to 11.0 by the gradual addition of lime slurry. The treated effluents were characterized primarily in terms of COD and conductivity and we obtained lowest COD $\left(345 \mathrm{mg} \mathrm{O}_{2} / \mathrm{L}\right)$ and conductivity $\left(21.4 \mathrm{mS} / \mathrm{cm}\right.$ at $\left.30^{\circ} \mathrm{C}\right)$ values at $\mathrm{pH} 9$. Then a large scale treatment was carried out with $20.0 \mathrm{~L}$ of the effluent in the same experimental condition at $\mathrm{pH} 9$ and the removal of chromium, COD, TSS, TDS and conductivity (at $30^{\circ} \mathrm{C}$ ) were achieved up to $99.79,60.99,97.22,98.27$ and $41.85 \%$, respectively. Chloride concentration was also measured before and after treatment but no significant change was observed.
\end{abstract}

Keywords: Tanning; Effluent; ETP; Chemical precipitation; COD; TSS; TDS.

@ 2013 JSR Publications. ISSN: 2070-0237 (Print); 2070-0245 (Online). All rights reserved.

doi: http://dx.doi.org/10.3329/jsr.v5i1.12557 J. Sci. Res. 5 (1), 143-150 (2013)

\section{Introduction}

Bangladesh earns significant amount of foreign currency by exporting leather goods from its tanning industries. A recent report revealed that leather and leather products are one of the major external trade sectors which contribute up to $1.39 \%$ share on the total export earnings [1]. However, tanning industries pose a serious environmental hazard for Dhaka city, the hugely populated capital of Bangladesh.

Hazaribagh (Dhaka) and Kalurghat (Chittagong) are the two main tanning industry concentrated zones in Bangladesh. Hazaribagh is situated on the bank of the river

\footnotetext{
Corresponding author: sabur227@yahoo.com
} 
Buriganga and Kalurghat is on the bank of Karnaphuly river. Hazaribagh, the largest tanning industrial area of the country and situated on the south-west part of the capital city of Dhaka, has around 400 tanning units [2]. The River Buriganga is flowing on the western side of the area. The total households of the upazila are 25914 units and the total population is $1,27,370$ [3]. From the tanning units of Hazaribagh area, roughly $15000 \mathrm{~m}^{3}$ of untreated wastes containing various chemicals go to the low-lying areas and to the nearest water bodies including river Buriganga which is a major water source for agricultural purposes as well as for fishing activities for the local population [4].

The extremely colored tannery wastewater is acidic in nature with high chromium content including other pollution loads such as chemical oxygen demand, biochemical oxygen demand, dissolved salts etc. [5,6]. The discharge of the effluent prior to treatment is creating great environmental threats. Water in the river Buriganga is poisonous and black in color. The physical look and smell of the area is frightening and intolerable. People of Hazaribag area are somehow more or less dependent on the river water for their domestic purposes especially in the dry season when there is a scarcity of water. As a result, they are always facing food poisoning too. Several studies have been carried out about the pollution status of the Hazaribagh area [7-9].

The inhabitants of the area want to get rid of unhygienic chromium contaminated environment. The Government of the People's Republic of Bangladesh decided to shift the tannery industries from Hazaribagh to Baliapore which is only about fifteen kilometer away from the Dhaka City [2]. The river Bongshy is flowing beside the fore coming location of tannery industrial zone at Baliapore and is also connected to the river Buriganga on its way. But the shifting is now getting delayed over the last decade due to the delay in setting up of the common effluent treatment plant (ETP) for the proposed industrial zone. Unwillingness of the owners is also a factor for the delay.

Untreated wastewater from tannery industries is causing unfavorable chromium contaminated environment for living beings in the area. Microbiological analyses indicated that the contaminated area is affected by fecal pollution and the environmental health risks are increasing with an alarming rate [10]. Chromium exists in two forms; trivalent and hexavalent, where hexavalent form is more toxic than its trivalent form [5]. The highly toxic hexavalent chromium is more mobile in the environment and hence more bioavailable. It affects skin and stomach at short-term exposure beyond the allowable contaminant level, long-term exposure at the same level can cause damage to liver, kidney and nerve function, and sometimes ultimate result is death at higher doses [11]. Trivalent chromium is only toxic above a certain concentration but within the allowable range, it is an essential micronutrient for some metabolic processes in human bodies [12].

There are two common types of tanning systems, vegetable tanning which is not chromium based and chrome tanning, the most common type of tanning processes where large amount of chrome powder and liquor are used [6, 13-15]. In the second method, the collagen parts of hides form complexes with chromium and changes to leather. Chromium salts (particularly chromium sulphate) are the most widely used tanning substances and hides tanned with chromium salts exhibit a good mechanical resistance [16, 17]. From the 
tanning process, significant portions of unused chromium remains in the tanning exhaust and contaminates water, soil and hence are accumulated by various food grains causing a detrimental effect in the corresponding area [16]. A number of methods such as reverse osmosis, ion exchange, electrodialysis, surface adsorption, biosorption etc. are frequently used for the removal of chromium and other heavy metals [18]. Bioremediation technique can remove chromium effectively but other effluent quality parameters are not considered there $[19,20]$. Tannery effluent can also be treated by chemical precipitation method by raising $\mathrm{pH}$ of the effluent using both sodium and magnesium hydroxides [21]. Treatment based on chemical coagulation has also been studied [22]. Conventional chrome tanning results in wastewater containing as high as $1500-3000 \mathrm{mg} / \mathrm{L}$ of chromium [23]. There are some available methods where up to $99 \%$ removal of chromium is possible $[16,17,19$, 24] and usually these sorts of technologies are complicated, expensive and energy intensive and some technologies are not yet in practice widely.

Due to high correlation between chrome tanning and its environmental impact, costeffective alternative technologies for the treatment of tannery wastewater are required. The objectives of the present work is to characterize the wastewater discharged from tannery industries and their treatment for the removal of chromium and other undesirable materials by using low cost locally available commercial grade lime by chemical precipitation method and to make it up to standard for the discharge to the neighboring water bodies or to the environment.

\section{Experimental}

Around $50.0 \mathrm{~mL}$ effluent sample was collected in a plastic container (previously washed with dilute $\mathrm{HNO}_{3}$ ) from the Chowdhury Tannery, Hazaribag, Dhaka, when it was in operational condition. A few $\mathrm{mL}$ of conc. $\mathrm{HNO}_{3}$ was added to the effluent to prevent the growth of microbial and was sealed to avoid possible air oxidation. The raw effluent was then analyzed for some physico-chemical parameters such as $\mathrm{pH}$, total chromium, chemical oxygen demand (COD), total suspended solids (TSS), total dissolved solids (TDS), chloride concentration etc. within $72 \mathrm{~h}$ of the sample collection.

Initially batch experiments were carried out with $200 \mathrm{~mL}$ effluents in five $500 \mathrm{~mL}$ beakers and $\mathrm{pHs}$ of each solution were adjusted to $6,7,8,9,10$ and 11 using lime slurry prepared by mixing solid lime (dried at $110^{\circ} \mathrm{C}$ ) with water. With the addition of lime slurry, blue coloured precipitation was noticed, settle down rapidly at the bottom of the beakers. The whole systems were allowed to stand for around $6 \mathrm{~h}$ and then the supernatants were separated from the deposited sludge. The COD and conductivity of the treated effluents were analyzed and based on these results, dosages and other operational conditions were optimized initially. From the results, it was observed that the quality of the treated effluents was better at $\mathrm{pH}$ 9 compared to the trials at other pHs. Then further treatment to a greater extent was carried out with $20.0 \mathrm{~L}$ effluent and lime slurry was added gradually until $\mathrm{pH}$ of the system reached 9.0. 
$\mathrm{pH}$ was measured at different stages of our study by a digital pH meter (CG-818, Schott Gerate), TSS was determined by filtering a well-mixed sample through a weighed standard glass-fiber filter and the residue retained on the filter was dried to a constant weight at $103-105^{\circ} \mathrm{C}$, the increase in weight of the filter represents the TSS. The filtrate obtained from the TSS determination was evaporated at $180^{\circ} \mathrm{C}$ and the TDS was determined gravimetrically. Conductivity was recorded using a digital conductivity meter (RM6 LAUDA) and the COD was measured by open reflux method. Extraction of chromium from the sludge was carried out by digesting the dried sludge using concentrated $\mathrm{H}_{2} \mathrm{SO}_{4}$ on a sand bath at $100^{\circ} \mathrm{C}$ for $3 \mathrm{~h}$ and the leachate obtained was diluted with distilled water to the desired level for the determination of chromium. Flame atomic absorption spectrophometric method was used to quantify chromium. Chloride was estimated by treating specific amount of effluent with excess standard $\mathrm{AgNO}_{3}$ solution followed by back titration with a standard solution of ammonium thiocyanate. All the experiments were carried out in the Department of Cchemistry and in Wazed Miah Science \& Research Centre, Jahangirnagar University.

\section{Results and Discussion}

Physical and chemical characteristics of the tannery effluent before the treatment were determined through enormous laboratory analyses and it was observed that the raw effluent contained chromium $\left(\mathrm{Cr}^{3+} / \mathrm{Cr}^{6+}\right)$ in high concentration $(987 \mathrm{mg} / \mathrm{L})$. COD, TSS, TDS and conductivity were also high for the presence of various chemicals used for leather processing as well as for the dissolved protein part (e.g. collagen) from the leather. UV spectrophotometric analysis is a proven method to investigate the progress of wastewater treatment $[25,26]$. In the present study the spectra collected at various stages of the treatment and these are presented here for both untreated and treated effluents (large scale) (Fig. 1).
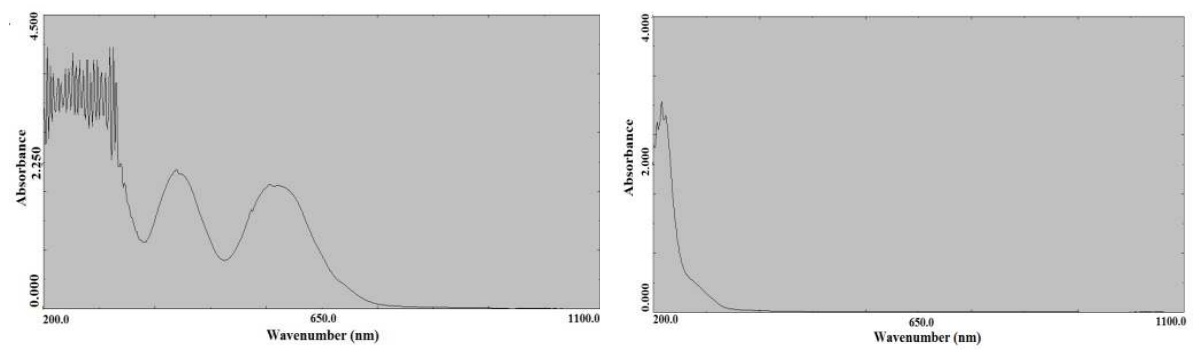

Fig. 1. UV visible spectra of both untreated (left) and treated effluent (right).

It clearly shows that the absorbance of the effluent at various wavelengths decreases as the $\mathrm{pH}$ increases up to $\mathrm{pH} 9$ and then increases again (all the spectra have not been shown here). In addition to this, other effluent quality parameters such as COD and conductivity 
were determined to see clearly at which $\mathrm{pH}$ we are getting better treatment. From the treatments in different $\mathrm{pH}$ conditions, significant variation of COD and conductivity were observed and can be illustrated by Figs. 2 (a)-(b).
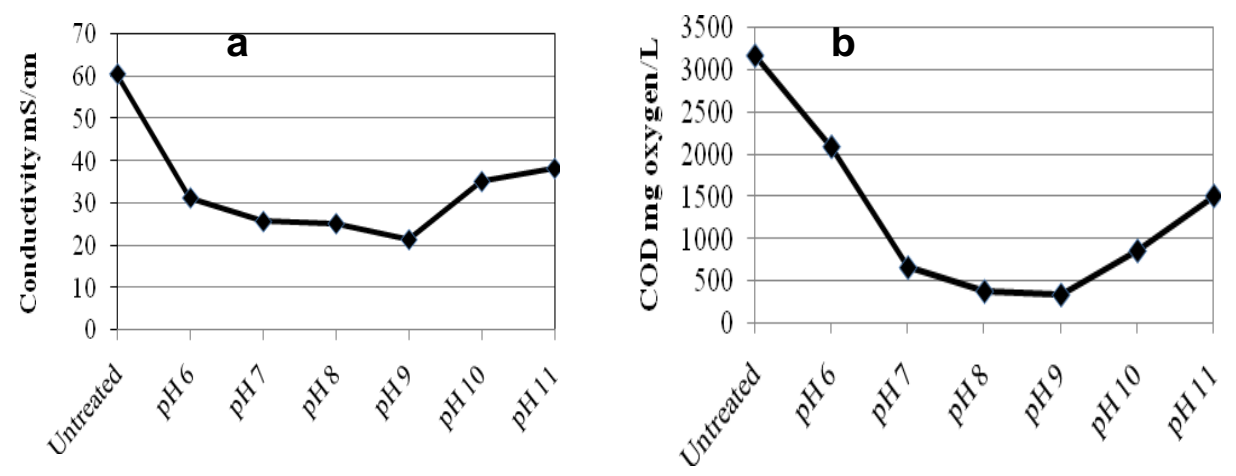

Fig 2. $\mathrm{pH}$ dependence variation of (a) conductivity, and (b) COD.

The minimum conductivity of the treated effluent at $\mathrm{pH} 9$ means that the ionic mobility becomes the lowest at this specific condition which can be explained by the coprecipitation of most of the ions with $\mathrm{Cr}(\mathrm{OH})_{3}$. When treated at $\mathrm{pH}$ value greater than 9.0, the conductivity of the effluent starts increasing further. COD of the treated effluents decreases initially and then increases with increasing $\mathrm{pH}$ as observed in case of conductivity and it reached to the lowest value when treated at $\mathrm{pH}$ 9.0. In this treatment, most of the organic matters and the other chemicals responsible for COD are considered to get co-precipitated with colloidal $\mathrm{Cr}(\mathrm{OH})_{3}$. At comparatively lower $\mathrm{pH}$, formation of $\mathrm{Cr}(\mathrm{OH})_{3}$ was not sufficient and hence not suitable for coagulation. Besides this, at $\mathrm{pH}$ above 9.0, the chromium re-dissolves and concentration of chromium in the supernatant increases and therefore the condition is not favorable for coagulation and precipitation [21].

The large scale treatment was then used to measure COD, conductivity, chloride concentration, and TDS and the results are shown in the Table 1. In the large scale treatment, the values of effluent quality parameters are slightly greater than those obtained from the small scale treatment. This is probably because of the difficulties in the adjustment of $\mathrm{pH}$ perfectly for such large volume of effluent.

The sludge obtained from the treatment $(20.0 \mathrm{~L})$ was dried at $120^{\circ} \mathrm{C}$ that gave a mass of $\sim 180 \mathrm{~g}$. A major drawback with any such treatment system is sludge production and is complicated for its management [25]. However, our results from the preliminary leaching experiment show that the sludge obtained was enriched in high chromium content; $9.19 \%$ as dry weight basis of the sludge. The recovered chromium liquor can also be used for further tanning process [27]. So, if this chromium rich liquor can be used in further tanning process, a huge expenditure for the import of chromium salt will then be reduced. 
In addition to this, recovery and reuse of tannery sludge as a source of chromium will also decrease the chromium pollution in the environment.

Table 2. Physical and chemical characteristics of the untreated and treated effluent (large scale).

\begin{tabular}{lcc}
\hline Parameters & Untreated effluent & Treated at pH 9 (large scale) \\
\hline Colour & Deep blue & Colourless \\
Odor & Leather type & Bit leather type \\
$\mathrm{pH}$ & 3.94 & 7.10 \\
Total chromium $(\mathrm{ppm})$ & 987.0 & 2.108 \\
$\mathrm{COD}\left(\mathrm{mg} \mathrm{O}_{2} / \mathrm{L}\right)$ & 3175.32 & 1238.76 \\
$\mathrm{TSS}(\mathrm{mg} / \mathrm{L})$ & 22915.0 & 638.0 \\
$\mathrm{TDS}(\mathrm{mg} / \mathrm{L})$ & 13360.0 & 231.0 \\
Conductivity at $30^{\circ} \mathrm{C}(\mathrm{mS} / \mathrm{cm})$ & 60.7 & 35.3 \\
Chloride & 18800.8 & 20590.0 \\
\hline
\end{tabular}

\subsection{Comparison of treated effluent with the raw effluent}

The comparative study for some effluent quality parameters of the raw effluent and the treated effluent are presented in Table 1 where the $\mathrm{pH}$ of the treated effluent is 9 . Concentration of total chromium drops down from 987 to $2.108 \mathrm{mg} / \mathrm{L}$ with a removal of $99.79 \%$ of chromium and is thus perfectly suitable for releasing to the nearest water bodies or to the environment. Electronic conductivity was also decreased to $41.85 \%$ and can not be reduced to a greater extent as observed in case of chromium concentration; this might be due to some ionic species which do not get precipitated with gelatinous colloidal $\mathrm{Cr}(\mathrm{OH})_{3}$. The initial value of $\mathrm{COD}$ was $3175.32 \mathrm{mg} \mathrm{O} / \mathrm{L}$ and after treatment it was decreased to 1238.76 . That is through this treatment, COD was removed by $60.99 \%$. The decreasing trend of COD indicates that significant amount of organic wastes were suspended with $\mathrm{Cr}(\mathrm{OH})_{3}$ and most of them were removed from the system as sludge. TSS and TDS values of the treated effluent decreased in an appreciable amount. The particles and compounds responsible for TSS and TDS were seen to decrease by $97.22 \%$ and $98.27 \%$, respectively due to their co-precipitation with $\mathrm{Cr}(\mathrm{OH})_{3}$ as happened in the case of COD.

\section{Conclusion}

The government of Bangladesh has set the characteristics of effluent at discharge point for industrial units and projects [28] in which total chromium should not exceed $0.5 \mathrm{mg} / \mathrm{L}$ for in-land surface water. But for large processing units, the value is allowable up to 2.0 $\mathrm{mg} / \mathrm{L}$. According to this discharge quality standard to inland surface water, the maximum permissible limit for $\mathrm{pH}, \mathrm{COD}$, TSS, TDS, electrical conductivity and chloride content are 
6-9, $200 \mathrm{mg} \mathrm{O} / 2,150 \mathrm{mg} / \mathrm{L}, 2100 \mathrm{mg} / \mathrm{L}, 1.200 \mathrm{mS} / \mathrm{cm}$ and $600 \mathrm{mg} / \mathrm{L}$, respectively. Higher values are sometimes allowable for the discharge to public sewer or to irrigated land. Thus, from the results of our treatment, the treated effluent can be considered suitable for its discharge practically to the nearest water bodies. The result from the leaching experiments indicates that the extracted chromium can be reused for further tanning. However, it should be mentioned that chromium liquor produced in such a manner may contain dirt and other undesirable materials which should be removed before it is subjected to further tanning.

\section{References}

1. EPB (Export Promotion Bureau), Ministry of Commerce, The Peoples Republic of Bangladesh, Annual Report, Chapter 9 (2009-2010).

2. S. Safiullah, Theme Lecture, Bangladesh Chemical Congress, 33rd Annual Conference, 30 (2010).

3. BBS (Bangladesh Bureau of Statistics), Statistics Division, Ministry of Planning, The Peoples Republic of Bangladesh, Official website, Date accessed: 27 November 2011.

4. UNIDO: Regional programme for pollution control in the tanning industry in south-east Asia: Chrome balance in leather processing (2000).

5. Z. Kowalski and J. Hazard. Mater 37(1), 137 (1994). http://dx.doi.org/10.1016/0304-3894(94)85042-9

6. K. J. Sreeram and T. Ramasami, Resources, Conservation and Recyc. 38, 185 (2003). http://dx.doi.org/10.1016/S0921-3449(02)00151-9

7. M. A. Kashem and B. R. Singh, Water Air Soil Pollut. 115, 347 (1999). http://dx.doi.org/10.1023/A:1005193207319

8. A. Zahid, K. D. Balke, M. Q. Hassan, and M. Flegr, Environ. Geol. 50, 495 (2006). http://dx.doi:10.1007/s00254-006-00225-1

9. K. M. Shams, G. Tichy, A. Fischer, K. Filip, M. Sager, A. Bashar, T. Peer, and M. Jozic, Geophys. Res. Abstr. 10 (2008).

10. C. R. Arias-Barreiro, H. Nishizaki, K. Okubo, I. Aoyama, and I. C. Mori, J. Environ. Biol. 31, 471 (2010).

11. J. Kotas and Z. Stasicka, Environ. Pollut. 107 (3), 263 (2000). http://dx.doi.org/10.1016/S0269-7491(99)00168-2

12. D. E. Kimbrough, Y. Cohen, A. M. Winer, L. Creelman, and C. A. Mabuni, Critical Rev. Environ. Sci. Technol. 29 (1), 1 (1999).

13. M. S. Islam, M. T. H. Chowdhury, M. M. Rahman, and M. A. Hossain, Urban Ecosystems 7(4), 341 (2004). http://dx.doi.org/10.1007/s11252-005-6834-8

14. K. Nath, D. Singh, S. Shyam, and Y. K. Sharma, J. Environ. Biol. 30, 227 (2009).

15. V. J. Sundar, J. R. Rao, and C. Muralidharan, J. clean. product. 10, 69 (2002). http://dx.doi.org/10.1016/S0959-6526(01)00015-4

16. A. A. Belay, J. Environ. Protect. 1, 53, (2010). http://dx.doi:10.4236/jep.2010.110077

17. N. F. Fahim, B. N. Barsoum, A. E. Eid, and M. S. Khalil, J. Hazard. Mater. B 136, 303 (2006). http://dx.doi:10.1016/j.jhazmat.2005.12.0144

18. S. E. Manahan, Environmental Chemistry, 8th ed. (CRC Press, New York, Washington, D.C., 2000).

19. J. F. Benazir, R. Suganthi, D. Rajvel, M. P. Pooja, and B. Mathithumilan, Afric. J. Biotechnol. 9 (21), 3140 (2010).

20. M. N. Sepehr, S. Nasseri, M. M. Assadi, and K. Yaghmaian, Iran. J. Environ. Health Sci. Eng. 2, 273 (2005). 
21. A. Esmaeili, A. M. Nia, and R. Vazirinejad, Am. J. App. Sci. 2 (10), 1471 (2005). http://dx.doi:10.3844/ajassp.2005.1471.14733

22. Z. Song, C. J. Williams, and R. G. J. Edyvean, Desalination 164, 249 (2004). http://dx.doi.org/10.1016/S0011-9164(04)00193-6

23. V. Suresh, M. Kanthimathi, P. Thanikaivelan, J. R. Rao, and B. U. J. Nair, Clean. Prod. 9, 483, (2001). http://dx.doi.org/10.1016/S0959-6526(01)00007-5

24. R. Aravindham, B. Madhan, J. R. Rao, B. U. Nair, and T. Ramasami, Environ. Sci. Technol. 38, 300 (2004). http://dx.doi.org/10.1021/es034427s

25. M.A. Sabur, A. A. Khan, and S. Safiullah, J. Sci. Res. 4 (3), 623 (2012). http://dx.doi.org/10.3329/jsr.v4i3.107777

26. O. Thomas, E. Baures, and M. F. Pouet, Water Qual. Res. J. Canada 40 (1), 51 (2005).

27. J. Landgrave, Environ. Health Perspect. 103 (1), 63 (1993). http://dx.doi.org/10.1289/ehp.95103s163

28. GAETP (Guide for Assessment of Effluent Treatment Plants), 1st ed. (Department of Environment, Ministry of Environment and Forest, Bangladesh, 2008). 